\title{
INTERNATIONAL RESEARCH JOURNAL OF PHARMACY
}

www.irjponline.com

ISSN $2230-8407$

\section{Research Article}

\author{
QSAR MODELING OF BENZOXAZINE-3-ONES DERIVATIVES AGAINST CANDIDA KRUSEI \\ Chaturvedi Neha $^{1 *}$, Chaturvedi Dev Sharan ${ }^{2}$, Mishra Ashutosh ${ }^{2}$, Bajpai Pawan ${ }^{2}$ and Neeraj Upmanyu ${ }^{2}$ \\ ${ }^{1}$ Department of Pharmaceutical Chemistry, R. K. D. F. College of Pharmacy, Bhopal (M.P), India \\ ${ }^{2}$ Daksh Institute of Pharmaceutical Science, Chhatarpur (M.P.), India \\ *Corresponding Author Email: ch.nehas@gmail.com
}

Article Received on: 17/09/13 Revised on: 21/11/13 Approved for publication: 30/12/13

\section{DOI: $10.7897 / 2230-8407.041216$}

ABSTRACT

QSAR Study on the inhibition of Candida krusei by Benzoxazine-3-ones derivative using several physiochemical descriptors was performed. Antifungal activity for 16 Benzoxazine-3-ones derivatives was modeled by using multiple regression procedure. The best model is selected $\mathrm{r}^{2}=0.9985$, adjusted $\mathrm{r}^{2}=$ 0.9981. The result obtained from QSAR studies could be used in designing better antifungal agent.

Keywords: Antifungal activity, Candida krusei, Benzoxazine -3-ones, QSAR

\section{INTRODUCTION}

Benzoxazine and its derivatives are used in organic synthesis for building natural and designed synthetic compounds and they have been frequently utilized as suitable skeletons for the design of biologically active compound ${ }^{1}$. The investigation of the QSAR of substance is an important aspect of modern chemistry, biochemistry, medicinal chemistry and drug discovery ${ }^{2}$. The information obtained is composed of mathematical equation relating the chemical structure of the compound to a wide variety of their physical, chemical, biological and technological properties ${ }^{3}$. Once a correlation between structure and activity is found, any number of compound, including those not synthesized yet, can be readily be screened for selection of structure with desired properties ${ }^{4}$. Hence it is possible to select the most promising compound for synthesis and testing in the laboratory ${ }^{5}$. Mycotic illness in human are divided into three groups: contagious skin and hair infection, non contagious soil borne or air borne systemic infection and non contagious food borne toxemias ${ }^{6}$. The responsible organisms and method of prevention and treatment differ with each group ${ }^{7}$. The prevalence of systemic fungal infection has increased significantly during the past decade ${ }^{8}$. The fungal infection is mainly cause by a Candida species ${ }^{9}$. This increase is due to greater use of broad-spectrum antibiotics, immunosuppressive agent, center venous catheters, intensive care low birth weight infants, organ transplantation and the acquired immunodeficiency syndrome (AIDS) epidemic ${ }^{10}$. Candida krusei is budding yeast involved in the chocolate production, Candida krusei is an emerging fungal nosocomial pathogen primarily found in the immune compromised and those with hematological malignancies ${ }^{11}$. It has natural resistance to fluconazole, a standard antifungal agent ${ }^{12}$. Infection generally occurs when a person's immune system is compromised to some degree, causing the Candida cell to colonize in various areas within the body ${ }^{13}$. In patient with a deficiency in their immune system, Candida krusei can lead to a more systemic illness ${ }^{14}$. The uses of antifungal drug is limited and restricted due to rapid development of drugs resistance. They also produce the side effect in the prolonged uses. Therefore the development of new class of drugs as a potent antifungal is becomes a crucial point. A group of drugs 1, 4-benzoxazine-3-ones was extracted from rye, wheat, maize. 2, 4-dihydroxy-1, 4-benzoxazine-3-one (DIBOA) Figure 1 and its methoxy derivative (DIMBOA) Figure 1 have been shown to inhibited germination of spore of phytopathogenic fungi and play an important role in defense of cereal against deleterious pest such as insect, pathogenic fungi and bacteria .

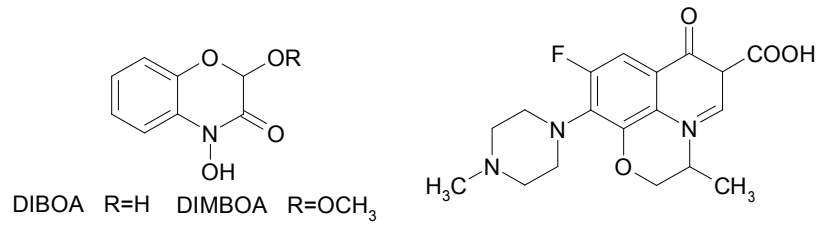

OFLOXACINE

Figure 1: Biologically active 1, 4 benzoxazines

These molecules are naturally present in plants as plants as glucosidase from which aglycones are released rapidly by enzymatic hydrolysis after physical and biological injury to plant and shows antifungal, antibacterial, insecticide effects. Now-a-days only limited numbers of compounds congaing 1 , 4-benzoxazine ring have been studied i.e. ofloxacine (Figure $1)^{15}$. So it is prolific to further investigate the nucleus with different substitutions with expected positive results with different physiological parameters. In the present study, we have performed the QSAR analysis by various regression methods. Regression methods are used to build a QSAR model in the form of a mathematical equation. This equation explains variation of dependent in terms of independent variables.

\section{Experimental}

The data set of 16 molecules with their antifungal activity has been taken from the literature ${ }^{16}$. The observe $\log 1 / \mathrm{C}$ value is given in Table 1 (Define the Activity in term of $\log 1 / \mathrm{C}$ ). All structures of benzoxazine derivative are sketched by using chem. sketch software ${ }^{17}$. The multiple regression analysis programs are done by $\mathrm{NCSS}^{18}$. The descriptors are calculated 
like thermodynamic, electronic, stearic and topological parameter. Thermodynamic parameter describes free energy change during drug receptor complex formation. Spatial parameters are the quantified steric features of drug molecule required for its complimentary fit with receptor. Electronic parameter describes weak non covalent bonding between drug molecule and receptor. The physico-chemical parameters Molecular weight (MW), Molar refractivity (MR), Molar volume (MV), Parachor (PC), Index of refraction (IR), Density (d), Polarizability (POL) were calculated by chem. sketch software by ACD labs. These calculated parameters and their values are reported in Table 2. The correlation matrix showing inter-correlation among the descriptors are reported in Table 3 a value more than 0.7 will indicate auto-correlation. A perusal of this Table clearly indicates that many indices highly correlated with each other. In sequential multiple regression the program search for all permutation and combination sequentially for the data set. The best model was selected from the various statistically significant equation on the basis of observed squared correlation coefficient $\left(\mathrm{r}^{2}\right)$, the standard error of the estimate (Se), Fisher test $(\mathrm{F})$, the bootstrapping standard deviation (Sbs), the cross-validated squared correlation coefficient using leave-one-out procedure $\left(\mathrm{q}^{2}\right)$.<smiles>[R]c1cc2c(cc1[R])N([R])C(=O)C(CC(=O)OCC)O2</smiles>

Table 1: Benzoxazine -3-one derivative used in this study

\begin{tabular}{|c|c|c|c|c|}
\hline $\begin{array}{c}\text { Compd. } \\
\text { No. }\end{array}$ & $\mathbf{R}$ & $\mathbf{R}_{\mathbf{1}}$ & $\mathbf{R}_{\mathbf{2}}$ & $\begin{array}{c}\text { Obs. log } \\
\mathbf{1} / \mathbf{C}\end{array}$ \\
\hline 1. & $\mathrm{H}$ & $\mathrm{H}$ & $\mathrm{H}$ & 3.973 \\
\hline 2. & $\mathrm{H}$ & $\mathrm{CH}_{3}$ & $\mathrm{H}$ & 3.998 \\
\hline 3. & $\mathrm{H}$ & $\mathrm{Cl}$ & $\mathrm{H}$ & 4.032 \\
\hline 4. & $\mathrm{H}$ & $\mathrm{COOC}_{2} \mathrm{H}_{5}$ & $\mathrm{H}$ & 4.089 \\
\hline 5. & $\mathrm{H}$ & $\mathrm{H}$ & $\mathrm{NO}_{2}$ & 4.049 \\
\hline 6. & $\mathrm{H}$ & $\mathrm{Cl}$ & $\mathrm{NO}_{2}$ & 4.099 \\
\hline 7. & $\mathrm{CH}_{3}$ & $\mathrm{H}$ & $\mathrm{H}$ & 3.998 \\
\hline 8. & $\mathrm{CH}_{3}$ & $\mathrm{CH}$ & $\mathrm{H}$ & 4.022 \\
\hline 9. & $\mathrm{CH}_{3}$ & $\mathrm{Cl}$ & $\mathrm{H}$ & 4.054 \\
\hline 10. & $\mathrm{CH}_{3}$ & $\mathrm{COOC} \mathrm{H}_{5}$ & $\mathrm{H}$ & 4.106 \\
\hline 11. & $\mathrm{CH}_{3}$ & $\mathrm{Cl}$ & $\mathrm{NO}_{2}$ & 4.118 \\
\hline 12. & $\mathrm{CH}_{3}$ & $\mathrm{H}$ & $\mathrm{NO}_{2}$ & 4.070 \\
\hline 13. & $\mathrm{C}_{2} \mathrm{H}_{5}$ & $\mathrm{H}$ & $\mathrm{H}$ & 4.022 \\
\hline 14. & $\mathrm{C}_{2} \mathrm{H}_{5}$ & $\mathrm{Cl}$ & $\mathrm{H}$ & 4.075 \\
\hline 15. & $\mathrm{C}_{2} \mathrm{H}_{5}$ & $\mathrm{H}$ & $\mathrm{NO}_{2}$ & 4.091 \\
\hline 16. & $\mathrm{C}_{2} \mathrm{H}_{5}$ & $\mathrm{Cl}$ & $\mathrm{NO}_{2}$ & 4.136 \\
\hline
\end{tabular}

Table 2: Values of the calculated physicochemical parameters used in the present study

\begin{tabular}{|c|c|c|c|c|c|c|c|c|}
\hline Compd. No & MW & MR & MV & PC & IR & ST & D & POL \\
\hline 1. & 235.236 & 59.26 & 193.9 & 489.9 & 1.523 & 40.7 & 1.213 & 23.49 \\
\hline 2. & 249.263 & 64.09 & 210.1 & 528.2 & 1.521 & 39.9 & 1.185 & 25.4 \\
\hline 3. & 269.68 & 64.16 & 205.8 & 527.1 & 1.535 & 42.9 & 1.31 & 25.43 \\
\hline 4. & 307.299 & 75.67 & 248.3 & 633.9 & 1.521 & 42.4 & 1.237 & 29.99 \\
\hline 5. & 280.24 & 65.81 & 205.7 & 547 & 1.552 & 49.9 & 1.362 & 26.08 \\
\hline 6. & 314.679 & 70.7 & 217.6 & 584.1 & 1.563 & 51.8 & 1.445 & 28.03 \\
\hline 7. & 249.263 & 64.19 & 208.9 & 528.1 & 1.526 & 40.8 & 1.193 & 25.44 \\
\hline 8. & 263.29 & 69.01 & 225.2 & 566.3 & 1.525 & 40 & 1.169 & 27.36 \\
\hline 9. & 283.7076 & 69.08 & 220.8 & 565.2 & 1.538 & 42.8 & 1.284 & 27.38 \\
\hline 10. & 321.326 & 80.59 & 263.3 & 672 & 1.524 & 42.4 & 1.22 & 31.95 \\
\hline 11. & 328.7052 & 75.63 & 232.7 & 622.3 & 1.563 & 51.1 & 1.412 & 29.98 \\
\hline 12. & 294.26 & 70.73 & 220.7 & 585.1 & 1.553 & 49.3 & 1.332 & 28.04 \\
\hline 13. & 263.29 & 68.81 & 226.5 & 568.1 & 1.519 & 39.5 & 1.162 & 27.27 \\
\hline 14. & 297.74 & 73.7 & 238.4 & 605.3 & 1.53 & 41.5 & 1.248 & 29.21 \\
\hline 15. & 308.287 & 75.35 & 238.3 & 625.2 & 1.545 & 47.3 & 1.293 & 29.87 \\
\hline 16. & 342.7317 & 80.25 & 250.2 & 662.3 & 1.554 & 49 & 1.369 & 31.81 \\
\hline
\end{tabular}

Table 3: Correlation matrix

\begin{tabular}{|c|c|c|c|c|c|c|c|c|c|}
\hline & Obs. & MW & MR & MV & PC & IR & ST & D & POL \\
\hline Obs. & 1.000 & & & & & & & & \\
\hline MW & 0.998 & 1.000 & & & & & & & \\
\hline MR & 0.914 & 0.916 & 1.000 & & & & & & \\
\hline MV & 0.775 & 0.777 & 0.959 & 1.000 & & & & & \\
\hline PC & 0.909 & 0.911 & 0.998 & 0.962 & 1.000 & & & & \\
\hline IR & 0.622 & 0.618 & 0.298 & 0.017 & 0.281 & 1.000 & & & \\
\hline ST & 0.677 & 0.674 & 0.369 & 0.103 & 0.369 & 0.969 & 1.000 & & \\
\hline D & 0.655 & 0.653 & 0.299 & 0.032 & 0.290 & 0.957 & 0.948 & 1.000 & \\
\hline POL & 0.914 & 0.916 & 1.000 & 0.959 & 0.998 & 0.298 & 0.370 & 0.299 & 1.000 \\
\hline
\end{tabular}

\section{RESULT AND DISCUSSION}

All the data presented in Table 2 have been subjected to regression analysis using NCSS software ${ }^{18}$. The regression analysis yielded in to 10 statistically significant models which are recorded in Table 4. Cross validation has been done by using leave one out (LOO) procedure. Best three models are obtained.

\section{One-variable model}

Out of 8 one-variable model MW has been found to be the best in model. $\log 1 / \mathrm{C}=0.0015( \pm 0.0000) \mathrm{MW}+3.6229$

$\mathrm{n}=16, \mathrm{R}^{2}=0.9970, \mathrm{R}^{2} \mathrm{~A}=0.9968, \mathrm{Se}=0.0007, \mathrm{~F}=4614.032, \mathrm{Q}=1426.427$

Here and here after the $\mathrm{n}$ is the total number of compounds; Se is the standard error of estimation; $\mathrm{R}^{2}$ is the correlation coefficient; $\mathrm{R}^{2}$ Adj is the adjusted $\mathrm{R}^{2}$; $\mathrm{F}$ is the Fisher's ratio and $\mathrm{Q}$ is the pogliani's quality factor which is the ratio of $\mathrm{R} / \mathrm{Se}$

The $99.7 \%$ data has been found to be explained by the above model. MW is positive and the means that compounds with increase of MW value have increase activity. 


\section{Two variable model}

$\log 1 / \mathrm{C}=0.3403( \pm 0.0063) \mathrm{MV}+0.0019( \pm 0.0000) \mathrm{D}+3.1949$ $\mathrm{n}=16, \mathrm{R}^{2}=0.9982, \mathrm{R}^{2} \mathrm{~A}=0.9979, \mathrm{Se}=0.0005, \mathrm{~F}=3608.325, \mathrm{Q}=1998.199$ PRESS $/ \mathrm{SSY}=0.0018, \mathrm{~S}_{\mathrm{PRES}}=0.0027, \mathrm{PSE}=0.0025$

$\mathrm{MV}$ and $\mathrm{D}$ as correlating parameters has been found to be the best in twovariable models

The model showing $99.8 \%$ variance in the data; both the descriptor show positively results.

\section{Three variable model}

$\log 1 / \mathrm{C}=0.0015( \pm 0.0003) \mathrm{MV}+0.3135( \pm 0.0185) \mathrm{D}+0.0036( \pm 0.0024)$ POL +3.2278

$\mathrm{n}=16, \mathrm{R}^{2}=0.9985, \mathrm{R}^{2} \mathrm{~A}=0.9981, \mathrm{Se}=0.0005, \mathrm{~F}=2655.061, \mathrm{Q}=1998.499$ $\mathrm{PRESS} / \mathrm{SSY}=0.0015, \mathrm{~S}_{\mathrm{PRESS}}=0.0021, \mathrm{PSE}=0.0018$

$\mathrm{MV}, \mathrm{D}$ and POL as correlating parameter have been found to be the best Out of three-variable models.

This model has $\mathrm{R}^{2}=0.9985$. Suggesting that addition of POL in the two-parametric model is justified. This tri-parametric model has highest $\mathrm{Q}$ value suggesting this model to be the best among all the tried Three-variable models

Table 4: Regression parameters and quality of correlation when physicochemical parameters are used

\begin{tabular}{|c|c|c|c|c|c|c|c|c|}
\hline Model No. & Parameters used & $\mathbf{A i}=(1---3)$ & B & Se & $\mathbf{R}^{2}$ & $\mathbf{R}^{2} \mathbf{A}$ & $\mathbf{F}$ & $\mathbf{Q}$ \\
\hline 1. & IR & $1.8813( \pm 0.6335)$ & 1.1667 & 0.0095 & 0.3864 & 0.3426 & 8.818 & 65.433 \\
\hline 2. & $\mathrm{D}$ & $0.3534( \pm 0.1088)$ & 3.6069 & 0.0092 & 0.4296 & 0.3889 & 10.544 & 71.243 \\
\hline 3. & ST & $0.0073( \pm 0.0021)$ & 3.7353 & 0.0089 & 0.4585 & 0.4198 & 11.855 & 76.082 \\
\hline 4. & MV & $0.0020( \pm 0.0004)$ & 3.6180 & 0.0077 & 0.6002 & 0.5716 & 21.015 & 100.614 \\
\hline 5. & $\mathrm{PC}$ & $0.0008( \pm 0.0001)$ & 3.5741 & 0.0051 & 0.8266 & 0.8142 & 66.736 & 178.270 \\
\hline 6. & MR & $0.0071( \pm 0.0008)$ & 3.5573 & 0.0049 & 0.8349 & 0.8231 & 70.78 & 186.475 \\
\hline 7. & POL & $0.0179( \pm 0.0021)$ & 3.5576 & 0.0049 & 0.8350 & 0.8232 & 70.845 & 186.486 \\
\hline 8. & MW & $0.0015( \pm 0.0000)$ & 3.6229 & 0.0007 & 0.9970 & 0.9968 & 4614.032 & 1426.427 \\
\hline 9. & $\begin{array}{c}\text { MV } \\
\text { D }\end{array}$ & $\begin{array}{l}0.3403( \pm 0.0063) \\
0.0019( \pm 0.0000)\end{array}$ & 3.1949 & 0.0005 & 0.9982 & 0.9979 & 3608.325 & 1998.199 \\
\hline 10. & $\begin{array}{c}\text { MV } \\
\text { D } \\
\text { POL }\end{array}$ & $\begin{array}{l}0.0015( \pm 0.0003) \\
0.3135( \pm 0.0185) \\
0.0036( \pm 0.0024)\end{array}$ & 3.2278 & 0.0005 & 0.9985 & 0.9981 & 2655.061 & 1998.499 \\
\hline
\end{tabular}

Table 5: Observed and Estimated

\begin{tabular}{|c|c|c|c|}
\hline Compd. No. & Obs. $\log \mathbf{1} / \mathbf{C}$ & Est. $\log \mathbf{1} / \mathbf{C}$ & Residual \\
\hline 1. & 3.973 & 3.976 & -0.003 \\
\hline 2. & 3.998 & 3.998 & 0.000 \\
\hline 3. & 4.032 & 4.031 & 0.001 \\
\hline 4. & 4.089 & 4.087 & 0.002 \\
\hline 5. & 4.049 & 4.049 & 0.000 \\
\hline 6. & 4.099 & 4.100 & -0.001 \\
\hline 7. & 3.998 & 3.999 & -0.001 \\
\hline 8. & 4.022 & 4.022 & 0.000 \\
\hline 9. & 4.054 & 4.052 & 0.002 \\
\hline 10. & 4.106 & 4.110 & -0.004 \\
\hline 11. & 4.118 & 4.119 & -0.001 \\
\hline 12. & 4.070 & 4.069 & 0.001 \\
\hline 13. & 4.022 & 4.021 & 0.001 \\
\hline 14. & 4.075 & 4.073 & 0.002 \\
\hline 15. & 4.091 & 4.089 & 0.002 \\
\hline 16. & 4.136 & 4.137 & -0.001 \\
\hline
\end{tabular}

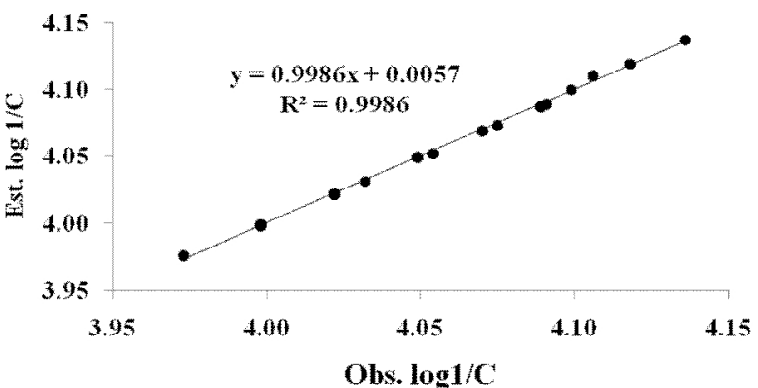

Figure 2: Observed vs estimted Log 1/c values using model no.10

The graph between experimental and predicted biological activity by using model 4 is shown in Figure

\section{CONCLUSION}

In the summary, from the derived QSAR model it can be concluded that antifungal activity of benzoxazine derivative against Candida krusei is strongly influenced by steric, electrostatic interaction and hydro phobic interaction nature of substituent. The model obtained by this study will used for designing of new compound.

\section{REFERENCE}

1. N Siddiqui, R Ali, MS Alam, W Ahsan. (1Z 2E) 1-(3, 4 -di phenyl 2, 3dihydro-1, 3 thiazol-1- ylidine)-2-(1-p-tolylethylidene) hydrazine, J. Chem. Pharm. Res 2010; 2: 309-316.

2. C Hansch, A Leo. Exploring QSAR: Fundamentals and Application in Chemistry and Biology, Amer. Chem. Soc 1995; 2: 306-315.

3. M Karelson, V Lobano, A Katritzky. Chem. Rev 1996; 96: 1027-1043. http://dx.doi.org/10.1021/cr950202r PMid:11848779

4. M Polyakova, LM Jin, KH Row. Effect of Concentration of Ionic Liquids on Resolution of Nucleotides in Reversed-phase Liquid Chromatography Bull. Korean Chem. Soc 2006; 27: 211-218.

5. JL Xu, SL Gao, XF Zhang, YP Xie. QSAR study on some newly synthesized pyrimidobenzimidazole derivatives as analgesic agents, Chinese J. Struct. Chem 2007; 26: 91-97.

6. P Vasanthanathan, M Lakshimi, M Babu, A Gupta, S Kaskhedikar. QSAR Study of 3-Phenyl-5- acyloxymethyl-2H, 5H-furan-2-ones as Antifungal Agents, Chem. Pharma. Bull 2006; 54: 583-587. http:// dx.doi.org/10.1248/cpb.54.583

7. PA Pizzo, LS Young. Empirical antibiotic therapy in febrile neutropenic cancer patient: clinical efficacy and impact of mono therapy, Am. J. Med 1984; 76: 101-110. http://dx.doi.org/10.1016/0002-9343(84)90327-

8. CE Gonzalez, D Venzon, S Lee, BU Mueller, PA Pizzo, TJ Walsh. Clin. Infect. Dis 1996; 23: 515-521. http://dx.doi.org/10.1093/clinids/23.3.515 PMid:8991477

9. JR Graybill. The future of antifungal therapy, Clin. infect. Dis 1996; 22: 166-168. http://dx.doi.org/10.1093/clinids/22.Supplement_2.S166

10. MA Pfaller, SA Messer, S Gee, S Joly, C Pujol, DJ Sullivan, DC Colemann, DR Soll. In vitro Susceptibilities of Candida dubliniensis Isolates tested against the New Triazole and Echinocandin Antifungal Agents, J. Clin. Microbial 1999; 37: 870-872. PMid:9986880 PMC id:PMC84591

11. MA Pfaller. Candida krusei, a Multidrug-Resistant Opportunistic Fungal Pathogen: Geographic and Temporal Trends from the ARTEMIS DISK Antifungal Surveillance Program, J. Clin. Microbiol 2008; 46: 515-521. http://dx.doi.org/10.1128/JCM.01915-07 PMid:18077633 PMCid:PM C2238087

12. PG Pappas, JH Rex, J Lee, RJ Hamill, RA Larsen, W Powderly, CA Kauffman, N Hyslop, JE Mangino, S Chapman, HW Horowitz, JE Edwards. Phase 2, Randomized, Dose-Ranging Study Evaluating the Safety and Efficacy of Anidulafungin in Invasive Candidiasis and Candidemia, Clin. Infect. Dis 2003; 37: 634-643. http://dx.doi.org /10.1086/376906 PMid:12942393 
13. A Viudes, J Peman, E Canton, P Ubeda, JL Lopez Ribot, M Gobernado. Routine Use of a Commercial Test, Glabrata rtt, for Rapid Identification of Candida glabrata in Six Laboratories, Eur. J. Clin. Microbiol. Infect. Dis 2002; 21: 767-774. http://dx.doi.org/10.1007/s10096-002-0822-1 PMid: 12461585

14. JR Wingard, WG Merz, MG Rinaldi, TR Johnson, JE Karp, R Saral N. Association of Torulopsis glabrata Infections with Fluconazole Prophylaxis in Neutropenic Bone Marrow Transplant Patients Engl. J. Med 1991; 325: 1274-1277.

15. S Alper Hayata, E Aki Sener, Tekiner Gulbas, I Yildiz, O Temiz. Eur. J. Med. Chem 2006; 41: 1398- 1404.
16. Chem Sketch: www.acdlabs.com; 2010.

17. NCSS, Kaysville utah. www.ncss.com; 2010

18. L Pogliani. Internet Electronic Journal of Molecular Design Chem. Rev 2000; 100: 3827.

\section{Cite this article as:}

Chaturvedi Neha, Chaturvedi Dev Sharan, Mishra Ashutosh, Bajpai Pawan and Neeraj Upmanyu. QSAR modeling of benzoxazine-3-ones derivatives against Candida krusei. Int. Res. J. Pharm. 2013; 4(12):70-73 http://dx. doi.org/10.7897/2230-8407.041216

Source of support: Nil, Conflict of interest: None Declared 